\title{
Data report: dissolved and particulate organic carbon in the deep sediments of IODP Site U1363 near Grizzly Bare seamount ${ }^{1}$
}

\author{
Huei-Ting Lin, ${ }^{2}$ Chih-Chiang Hsieh, ${ }^{2}$ James P. Cowen, ${ }^{2}$ and Michael S. Rappé ${ }^{3}$
}

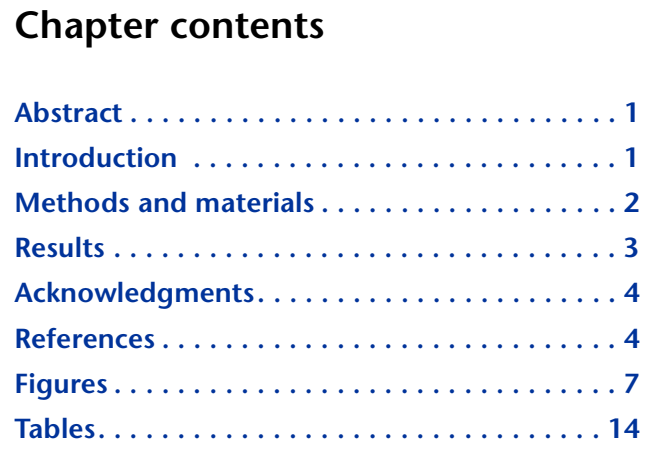

${ }^{1}$ Lin, H.-T., Hsieh, C.-C., Cowen, J.P., and Rappé, M.S., 2015. Data report: dissolved and particulate organic carbon in the deep sediments of IODP Site U1363 near Grizzly Bare seamount. In Fisher, A.T., Tsuji, T., Petronotis, K., and the Expedition 327 Scientists, Proc. IODP, 327: Tokyo (Integrated Ocean Drilling Program Management International, Inc.). doi:10.2204/iodp.proc.327.202.2015

${ }^{2}$ Department of Oceanography, SOEST, University of Hawaii, 1000 Pope Road, Honolulu HI 96822, USA. Correspondence author:

hueiting@hawaii.edu

${ }^{3}$ Hawaii Institute of Marine Biology, SOEST, University of Hawaii, PO Box 1346, Kaneohe HI 96744, USA.

\begin{abstract}
Marine sediments are a primary reservoir for the long-term storage of organic matter, and the rate of burial and oxidation of this sedimentary organic material help to regulate both atmospheric oxygen and carbon dioxide concentrations. To evaluate the impact of circulating basement fluid on the preservation of deeply buried organic carbon, sedimentary profiles of dissolved and particulate organic carbon (DOC and POC) near the sediment/basement interface were obtained from sediment coring at Site U1363 during Integrated Ocean Drilling Program Expedition 327. Sedimentary DOC increased from $0.25 \mathrm{mM}$ at $1 \mathrm{~m}$ below the seawater/sediment interface to a maximum of $0.86 \mathrm{mM}$ at mid-depth (8-11 meters below seafloor [mbsf]), before subsequently decreasing to a minimum of $0.10 \mathrm{mM}$ at the sediment/basement interface (222.7 mbsf). Thus, the oceanic basement appears to be a net sink for sedimentary DOC. Sedimentary DOC and alkalinity profiles were similar and inversely mirror those of sulfate, suggesting that the buildup of DOC in sediment pore water is related to remineralization of sedimentary POC. The sedimentary POC content at Site U1363 ranged from 47 to $391 \mu$ mol-C/g, with $\delta^{13} \mathrm{C}$ values from $-25.3 \%$ to $-22.4 \%$. The total particulate nitrogen (PN) content ranged from 4.1 to $32.9 \mu \mathrm{mol}-\mathrm{N} / \mathrm{g}$, with $\delta^{15} \mathrm{~N}$ values from $1.8 \%$ to $7.2 \%$ and a POC:PN ratio of $12 \pm 2(n=54)$. No depthspecific systematic variations in POC, $\mathrm{PN}, \mathrm{POC}: \mathrm{PN}$ ratio, $\delta^{13} \mathrm{C}-$ POC or $\delta^{15} \mathrm{~N}-\mathrm{PN}$ were detected, and no significant correlations between sedimentary DOC and POC concentrations were observed.
\end{abstract}

\section{Introduction}

Marine sediments are the primary long-term reservoir for organic matter (Emerson and Hedges, 1988), and the rates of burial and oxidation of sedimentary organic matter significantly contribute to regulating Earth's atmospheric oxygen and carbon dioxide concentrations (Holland, 1984; Holland et al., 1986; Berner, 1990). Buried particulate organic matter (POM) in the sediment is mobilized to inorganic compounds such as carbon dioxide and ammonium by aerobic and anaerobic respiration and to dissolved organic matter (DOM) by processes including microbial hydrolysis and anoxic fermentation (Laanbroek et al., 1982; Capone and Klein, 1988; Arnosti et al., 1994; Arnosti, 1995; Fenchel et al., 1998; Burdige, 2002, 2006). An imbalance between the produc- 
tion and consumption of DOM results in dissolved organic carbon (DOC) concentrations in the surface sediments typically an order of magnitude higher than those in the overlying seawater (e.g., Alperin et al., 1994, 1999; Burdige et al., 1999; Papadimitriou et al., 2002). As a result, the flux of DOC from marine sediments to overlying seawater is roughly equivalent to that of riverine input and is a net loss of carbon from sediments to the water column (Burdige et al., 1992, 1999).

In contrast to the numerous DOC profiles published from surficial $(<1 \mathrm{~m})$ marine sediments (e.g., Krom and Sholkovitz, 1977; Burdige et al., 1992, 1999; Alperin et al., 1994, 1999; Burdige and Homstead, 1994; Burdige and Zheng, 1998; Burdige, 2002, 2006), only a few studies have examined pore water DOC concentrations within profiles extending to greater sediment depths (Michaelis et al., 1982; Egeberg and Abdullah, 1990; Seifert et al., 1990; Wefer et al., 1998; Simoneit and Sparrow, 2002; Heuer et al., 2009). Although the DOC concentrations within surficial sediments generally increase exponentially with increasing depth from the seawater/sediment interface until reaching an asymptotic maximum, DOC concentrations within deep sediment pore water generally do not demonstrate such systematic variation with depth. At some locations, depth profiles of DOC concentrations are similar to concurrently measured total particulate organic carbon and inorganic carbon profiles (Simoneit and Sparrow, 2002), whereas at other locations significant increases in DOC concentrations have been observed at greater depths due to hydrothermal activity from below (Simoneit and Sparrow, 2002).

The lack of a predictable pattern in deep sediment DOC profiles suggests that the deep DOC cycle may be more complicated than that occurring within surficial sediments. It is also not clear if the impact of hydrothermal activity always results in an increase in sediment pore water DOC concentrations. The fact that DOC concentrations in warm $\left(65^{\circ} \mathrm{C}\right)$ basaltic rock basement hydrothermal fluids are lower than those in the bottom seawater (Lang et al., 2006; Lin et al., 2012) suggests that hydrothermally heated basement fluids can be a sink for deep sedimentary DOC (Lin et al., 2012) that may cause sedimentary pore water DOC concentrations to decrease with depth.

Particulate organic matter in deep-sea sediments acts as an important energy source for a diverse array of microbial metabolisms, including aerobic and anaerobic organotrophy using nitrate or sulfate as electron acceptors (Laanbroek et al., 1982; Capone and Klein, 1988; Fenchel et al., 1998). Major electron acceptors in deep sediments, such as oxygen, nitrate, and sul- fate, originate from bottom seawater, and the penetration depths of these electron acceptors vary based on their concentrations in overlying bottom seawater, the sedimentation rate, and reactivity of POM (e.g., D'Hondt et al., 2002, 2004; Hartnett and Devol, 2003; Fischer et al., 2009). On the Washington Margin and eastern flank of the Juan de Fuca Ridge in the northeastern Pacific Ocean, sediment pore water oxygen and nitrate is exhausted at a few centimeters below the seafloor (Hartnett and Devol, 2003), and sulfate is significantly depleted relative to seawater at several tens of meters below the seafloor (Elderfield et al., 1999; Wheat et al., 2013). However, below the region of sulfate depletion, sulfate concentrations increase toward the sediment/basement interface due to the supply of sulfate from basement fluids (Elderfield et al., 1999; Wheat et al., 2013). The supply of electron acceptors from the deep basement into the sediment has been suggested to support microbial metabolism within the deep-sediment biosphere (D'Hondt et al., 2004; Engelen et al., 2008). In addition, Grizzly Bare outcrop on the eastern flank of Juan de Fuca Ridge provides a conduit for bottom seawater to recharge and mix with older and more reacted (i.e., anoxic) basement fluids (Fisher et al., 2003; Hutnak et al., 2006; Wheat et al., 2013) and provides additional electron acceptors to basement fluids and subsequently into deep sediments.

Although terrigenous organic matter discharged to the ocean is generally thought to be efficiently remineralized (Keil et al., 1997; Galy et al., 2008), on the eastern flank of Juan de Fuca Ridge an unusually high amount of terrigenous-derived organic matter has accumulated in the deep sediments near the sediment/basement interface (Prahl et al., 1994; Hedges et al., 1999; Dickens et al., 2006). This unique setting provides additional value to the study of terrigenous carbon preservation and degradation. This study provides DOC and POM (carbon, nitrogen, and isotopic composition) profiles at locations where the impact of hydrothermal circulation in basaltic basement on deep sedimentary organic biogeochemistry can be investigated.

\section{Methods and materials}

\section{Sample collection and processing}

Samples used for this study were from sediment cores taken from Integrated Ocean Drilling Program (IODP) Holes U1363G, U1363F, U1363B, and U1363C/D located on the slope of Grizzly Bare outcrop on the eastern flank of Juan de Fuca Ridge (Table T1; Fig. F1). The sediment/basement interface at these holes are 17, 35, 57, and 231 meters below seafloor (mbsf), respectively (see the "Site U1363" 
chapter [Expedition 327 Scientists, 2011b]). Details of whole sediment and sediment pore water sampling are described previously (see the "Methods" chapter [Expedition 327 Scientists, 2011a]; Wheat et al., 2013). Briefly, sediment cores were collected using advanced piston coring (APC or " $\mathrm{H}$ " shown in Table T2) and extended core barrel (XCB or " $\mathrm{X}$ " shown in Table T2) systems on the R/V JOIDES Resolution. Once shipboard, roughly $10-40 \mathrm{~cm}$ of the whole-round sediment section was placed in a nitrogen-filled glove bag, and the outside $0.5 \mathrm{~cm}$ of the sediment core was carefully scraped using a polytetrafluoroethylene-coated spatula in order to remove potential contaminants, leaving a $\sim 5.8 \mathrm{~cm}$ diameter core. The remaining sediment $\left(238-1030 \mathrm{~cm}^{3}\right)$ was pressed using a titanium squeezer and hydraulic press piston to extract sediment pore water. The resulting pore water was then passed through a prewashed Whatman Number 1 qualitative filter paper above a titanium screen and collected in a combusted $\left(550^{\circ} \mathrm{C} ; 5 \mathrm{~h}\right)$ glass syringe, before being filtered through a prerinsed $(50 \mathrm{~mL}$ deionized water) $0.45 \mu \mathrm{m}$ pore-sized polysulfone membrane filter (Supor, Pall Corporation) and collected in an acidcleaned and combusted glass scintillation vial. The pore water samples were kept frozen at $-20^{\circ} \mathrm{C}$ until subsequently thawed on shore for analysis. Two blank samples that were collected by passing deionized water through the squeezer and filter series have DOC concentrations of 0.016 and $0.028 \mathrm{mM}$ using the method described below. These blank values are an order of magnitude lower than the DOC in environmental pore water measured in the current study.

Sections of sediment after pore water extraction were carefully wrapped in combusted aluminum foil and frozen at $-80^{\circ} \mathrm{C}$ shipboard. In a shore-based laboratory, $\sim 5 \mathrm{~g}$ of frozen whole sediment from each sample was subsampled with a clean stainless steel spatula. The whole sediment subsamples were subsequently placed in combusted glass scintillation vials, loosely covered with combusted aluminum foil, and dried in an oven at $60^{\circ} \mathrm{C}$. The dried sediment was powdered with a clean ceramic mortar for subsequent analysis as described below.

\section{Pore water-dissolved organic carbon}

Sedimentary pore water DOC concentrations were measured by high-temperature combustion using a Shimadzu TOC-VCSH analyzer. The combustion temperature was set at $720^{\circ} \mathrm{C}$ to ensure complete oxidation of organic matter. Samples were acidified to $\mathrm{pH}<2$ by the addition of $45 \mu \mathrm{L}$ of $2 \mathrm{M} \mathrm{HCl}$ to $3 \mathrm{~mL}$ samples. No acid contamination was observed based on monitoring the DOC value of low-carbon deionized water. Samples were purged with nitrogen gas within the autosampler syringe for $2 \mathrm{~min}$ in order to remove inorganic carbon. An injection volume of $150 \mu \mathrm{L}$ was used, with five or six injections per sample. The reproducibility between replicate injections was $<1 \mu \mathrm{M}$. Analytical reference materials (ARM) supplied by Dr. Dennis Hansell (RSMAS, University of Miami) were measured before, between, and after analysis of environmental samples (Sharp et al., 2002; Dickson et al., 2007). At least one ARM was measured every five samples. The average measured concentration of the ARM was $42 \pm 2 \mu \mathrm{M}(n=44)$; the reported value was $41-43 \mu \mathrm{M}$. Our detection limit for DOC concentrations was $\sim 2 \mu \mathrm{M}$.

\section{Sediment}

Whole sediment samples were analyzed for concentration and isotopic composition of total carbon, organic carbon, and total nitrogen using an elemental combustion system (Costech ECS 4010) connected inline to an isotope-ratio mass spectrometer (Thermo Finnigan Delta XP). The amount of powdered sediment used for the analyses was optimized to provide sufficient carbon and nitrogen for isotopic composition analysis and varied between 26 and $425 \mathrm{mg}$. A subset of samples was acidified by fuming with concentrated $\mathrm{HCl}$ (Hedges and Stern, 1984) in order to remove inorganic carbon and quantify the particulate organic carbon (POC) content. Acid fuming did not remove inorganic nitrogen, resulting in insignificant differences between whole and acidfumed total particulate nitrogen (PN) concentrations. Calibration for $\mathrm{C}$ and $\mathrm{N}$ concentration was performed by running reference materials with the environmental samples. The isotopic compositions of carbon and nitrogen are reported as $\delta$ values (e.g., $\delta^{13} \mathrm{C}$ and $\left.\delta^{15} \mathrm{~N}\right)$ expressed in permil (\%o):

$$
\delta=\left[\left(R_{\text {sample }} / R_{\text {standard }}\right)-1\right] \times 1000,
$$

where $R$ is the ${ }^{13} \mathrm{C} /{ }^{12} \mathrm{C}$ or ${ }^{15} \mathrm{~N} /{ }^{14} \mathrm{~N}$ ratio. The standards for carbon and nitrogen isotopic composition are Vienna Peedee belemnite (NBS 19) and air, respectively (Coplen et al., 1992; Coplen, 1994).

\section{Results}

The concentrations of DOC in sediment pore water at Site U1363 ranged from 0.10 to $0.86 \mathrm{mM}$ (Fig. F2; Table T2). For comparison, similar measurements from Ocean Drilling Program Hole 856 located at Middle Valley, also on the eastern flank of Juan de Fuca Ridge, ranged from 0.01 to $7.14 \mathrm{mM}$ (Simoneit and Sparrow, 2002). The lowest sedimentary DOC concentration was observed near the sediment/basement interface of Hole U1363D, but the concentra- 
tion was still nearly an order of magnitude higher than that in basement fluid collected by the IODP CORK in Hole U1301A, $55 \mathrm{~km}$ north of Site U1363 (0.10 versus $0.012 \mathrm{mM}$; Lin et al., 2012). It should be noted that the overall procedural blank for the measurement of DOC in basement fluid and bottom seawater was only $0.002 \mathrm{mM}$. In Hole U1363G, the sedimentary DOC concentration was $0.25 \mathrm{mM}$ in nearsurface sediment pore water collected from a sediment core depth of $1.4 \mathrm{mbsf}$, which is significantly higher than was found in background bottom seawater from this region (0.039 mM; Lin et al., 2012). Depth profiles of DOC concentrations at Site U1363 show a mid-depth (8-11 mbsf) maximum, unlike those from Middle Valley (Simoneit and Sparrow, 2002), which showed an increase toward the basement.

Interestingly, the depth profiles of DOC concentration parallel those of alkalinity and appeared to inversely mirror depth profiles of sulfate concentration (Fig. F2), suggesting that the buildup of DOC in sediment pore water might be related to remineralization of sedimentary POM. The correlation between sulfate and DOC concentration was high and indicated that $\sim 0.09 \mathrm{mM}$ of DOC was added to the pore water with every $1 \mathrm{mM}$ of sulfate removed (Fig. F3). Similarly, $\sim 0.07 \mathrm{mM}$ of DOC was added to pore water with an increase of $1 \mathrm{meq} / \mathrm{L}$ of alkalinity (i.e., $\sim 1 \mathrm{mM}$ increase of bicarbonate; Fig. F3). However, no significant correlation was found between DOC concentrations in the sediment pore water and the POC content of the sediment (Fig. F4).

No systematic variation of POC, PN, C/N, $\delta^{13} \mathrm{C}-\mathrm{POC}$, and $\delta^{15} \mathrm{~N}-\mathrm{PN}$ with depth was observed (Fig. F5), with the exception of a correspondence between POC and PN depth profiles. The POC content of sediment samples from Site U1363 ranged from 47 to $391 \mu \mathrm{mol}-$ $\mathrm{C} / \mathrm{g}(0.06-0.47 \mathrm{wt} \%)$, whereas $\mathrm{PN}$ ranged from 4.1 to $32.9 \mu \mathrm{mol}-\mathrm{N} / \mathrm{g}(0.006-0.044 \mathrm{wt} \%)$, which were significantly lower than those in rivers and continental-shelf deposits on the Washington Coast (POC = $\sim 3 \mathrm{wt} \%$; PN $=\sim 0.3 \mathrm{wt} \%$ ) (Keil and Fogel, 2001). The low POC and PN contents suggested that degradation of particulate organic matter had occurred or an accumulation of inorganic material diluted the POC and PN content. POC- $\delta^{13} \mathrm{C}$ values from Site U1363 sediment samples ranged from $-25.3 \%$ to $-22.5 \% 0$ (Table T2; Fig. F5). For comparison, the organic carbon isotopic composition of fresh marine plankton were measured at approximately $-20.5 \%$ and terrestrial debris at $-26 \%$ (Keil and Fogel, 2001). The similarity of POC and PN profiles resulted in relatively low variation in $\mathrm{C} / \mathrm{N}$ ratios $(12 \pm 2 ; n=54)$ (Figs. F6, F7), which were slightly higher than the Redfield ratio ( 6; Redfield, 1934) but significantly lower than terrestrial vascular plants (>20) (Meyers, 1994; Keil and Fogel, 2001). POC- $\delta{ }^{13} \mathrm{C}$ values and $\mathrm{C} / \mathrm{N}$ ratios of Site U1363 sediments suggested that the sediments at Site U1363 were likely a mixture of degraded plankton biomass and terrestrial debris. Some of the low POC and PN and high $\mathrm{C} / \mathrm{N}$ ratios corresponded to sandy intervals, an indication of the influence of sedimentary composition by turbidites (Fig. F5).

\section{Acknowledgments}

We thank the captain, crew, and Expedition 327 Shipboard Scientists on board the R/V JOIDES Resolution. Samples, shipboard pore water alkalinity, and sulfate data were provided by the Integrated Ocean Drilling Program (IODP). We thank Geoff Wheat and Samuel Hulme for extracting sediment pore water for this study, Joseph Lichwa at the Water Resources Research Center at the University of Hawaii for DOC analysis, and Elizabeth Gier at the Biogeochemical Stable Isotope Facility at the University of Hawaii for sediment composition analysis. Funding was provided by an IODP Expedition 327 participation grant (T327A4) and a Center for Dark Energy Biosphere Investigations (C-DEBI) grant to J.P. Cowen, both of which are part of National Science Foundation (NSF)-sponsored programs. This is SOEST contribution Number 9243 and C-DEBI contribution Number 236.

\section{References}

Alperin, M.J., Albert, D.B., and Martens, C.S., 1994. Seasonal variations in production and consumption rates of dissolved organic carbon in an organic-rich coastal sediment. Geochim. Cosmochim. Acta, 58(22):4909-4930. doi:10.1016/0016-7037(94)90221-6

Alperin, M.J., Martens, C.S., Albert, D.B., Suayah, I.B., Benninger, L.K., Blair, N.E., and Jahnke, R.A., 1999. Benthic fluxes and pore water concentration profiles of dissolved organic carbon in sediments from the North Carolina continental slope. Geochim. Cosmochim. Acta, 63(3-4):427-448. doi:10.1016/S0016-7037(99)00032-0

Arnosti, C., 1995. Measurement of depth- and site-related differences in polysaccharide hydrolysis rates in marine sediments. Geochim. Cosmochim. Acta, 59(20):42474257. doi:10.1016/0016-7037(95)00247-W

Arnosti, C., Repeta, D.J., and Blough, N.V., 1994. Rapid bacterial degradation of polysaccharides in anoxic marine systems. Geochim. Cosmochim. Acta, 58(12):2639-2652. doi:10.1016/0016-7037(94)90134-1

Berner, R.A., 1990. Atmospheric carbon dioxide levels over Phanerozoic time. Science, 249(4975):1382-1386. doi:10.1126/science.249.4975.1382

Burdige, D.J., 2002. Sediment pore waters. In Hansell, D.A., and Carlson, C.A. (Eds.), Biogeochemistry of Marine Dis- 
solved Organic Matter: Amsterdam (Academic Press), 611-663. doi:10.1016/B978-012323841-2/50015-4

Burdige, D.J., 2006. Biogeochemical processes in continental margin sediments, II. Sulfur, methane, and trace metal cycling. In Burdige, D. (Ed.), Geochemistry of Marine Sediments: Princeton, NJ (Princeton Univ. Press), 478-508.

Burdige, D.J., Alperin, M.J., Homstead, J., and Martens, C.S., 1992. The role of benthic fluxes of dissolved organic carbon in oceanic and sedimentary carbon cycling. Geophys. Res. Lett., 19(18):1851-1854. doi:10.1029/92GL02159

Burdige, D.J., Berelson, W.M., Coale, K.H., McManus, J., and Johnson, K.S., 1999. Fluxes of dissolved organic carbon from California continental margin sediments. Geochim. Cosmochim. Acta, 63(10):1507-1515. doi:10.1016/S0016-7037(99)00066-6

Burdige, D.J., and Homstead, J., 1994. Fluxes of dissolved organic carbon from Chesapeake Bay sediments. Geochim. Cosmochim. Acta, 58(16):3407-3424. doi:10.1016/ 0016-7037(94)90095-7

Burdige, D.J., and Zheng, S., 1998. The biogeochemical cycling of dissolved organic nitrogen in estuarine sediments. Limnol. Oceanogr., 43(8):1796-1813. http:// onlinelibrary.wiley.com/doi/10.4319/ 1o.1998.43.8.1796/abstract

Capone, D.G., and Klein, R.P., 1988. Comparison of microbial dynamics in marine and freshwater sediments: contrasts in anaerobic carbon catabolism. Limnol. Oceanogr., 33(4):725-749. http://onlinelibrary.wiley.com/doi/ 10.4319/1o.1988.33.4part2.0725/abstract

Coplen, T.B., 1994. Reporting of stable hydrogen, carbon, and oxygen isotopic abundances. Pure Appl. Chem., 66(2):273-276. doi:10.1351/pac199466020273

Coplen, T.B., Krouse, H.R., and Böhlke, J.K., 1992. Reporting of nitrogen-isotope abundances. Pure Appl. Chem., 64(6):907-908. doi:10.1351/pac199264060907

D’Hondt, S., Jørgensen, B.B., Miller, D.J., Batzke, A., Blake, R., Cragg, B.A., Cypionka, H., Dickens, G.R., Ferdelman, T., Hinrichs, K.-U., Holm, N.G., Mitterer, R., Spivack, A., Wang, G., Bekins, B., Engelen, B., Ford, K., Gettemy, G., Rutherford, S.D., Sass, H., Skilbeck, C.G., Aiello, I.W., Guerin, G., House, C.H., Inagaki, F., Meister, P., Naehr, T., Niitsuma, S., Parkes, R.J., Schippers, A., Smith, D.C., Teske, A., Wiegel, J., Naranjo Padillo, C., and Solis Acosta, J.L., 2004. Distributions of microbial activities in deep subseafloor sediments. Science, 306(5705):22162221. doi:10.1126/science.1101155

D'Hondt, S., Rutherford, S., and Spivack., A.J., 2002. Metabolic activity of subsurface life in deep-sea sediments. Science, 295(5562):2067-2070. doi:10.1126/science. 1064878

Dickens, A.F., Baldock, J.A., Smernik, R.J., Wakeham, S.G., Arnarson, T.S., Gélinas, Y., and Hedges, J.I., 2006. Solidstate ${ }^{13} \mathrm{C}$ NMR analysis of size and density fractions of marine sediments: insight into organic carbon sources and preservation mechanisms. Geochim. Cosmochim. Acta, 70(3):666-686. doi:10.1016/j.gca.2005.10.024

Dickson, A.G., Sabine, C.L., and Christian, J.R. (Eds.), 2007. Guide to best practices for ocean $\mathrm{CO}_{2}$ measure- ments. PICES Spec. Publ., 3. http://cdiac.ornl.gov/ oceans/Handbook_2007.html

Egeberg, P.K., and Abdullah, M.I., 1990. The diagenetic factors controlling the dissolved organic carbon (DOC) in pore water from deep sea sediments (ODP Leg 113, Weddell Sea). In Barker, P.F., Kennett, J.P., et al., Proc. ODP, Sci. Results, 113: College Station, TX (Ocean Drilling Program), 169-177. doi:10.2973/ odp.proc.sr.113.167.1990

Elderfield, H., Wheat, C.G., Mottl, M.J., Monnin, C., and Spiro, B., 1999. Fluid and geochemical transport through oceanic crust: a transect across the eastern flank of the Juan de Fuca Ridge. Earth Planet. Sci. Lett., 172(1-2):151-165. doi:10.1016/S0012821X(99)00191-0

Emerson, S., and Hedges, J.I., 1988. Processes controlling the organic carbon content of open ocean sediments. Paleoceanography, 3(5):621-634. doi:10.1029/ PA003i005p00621

Engelen, B., Ziegelmüller, K., Wolf, L., Köpke, B., Gittel, A., Cypionka, H., Treude, T., Nakagawa, S., Inagaki, F., Lever, M.A., and Steinsbu, B.O., 2008. Fluids from the ocean crust support microbial activities within the deep biosphere. Geomicrobiol. J., 25(1):56-66. doi:10.1080/ 01490450701829006

Expedition 327 Scientists, 2011a. Methods. In Fisher, A.T., Tsuji, T., Petronotis, K., and the Expedition 327 Scientists, Proc. IODP, 327: Tokyo (Integrated Ocean Drilling Program Management International, Inc.). doi:10.2204/iodp.proc.327.102.2011

Expedition 327 Scientists, 2011b. Site U1363. In Fisher, A.T., Tsuji, T., Petronotis, K., and the Expedition 327 Scientists, Proc. IODP, 327: Tokyo (Integrated Ocean Drilling Program Management International, Inc.). doi:10.2204/iodp.proc.327.106.2011

Fenchel, T., King, G.M., and Blackburn, H., 1998. Bacterial Biogeochemistry: The Ecophysiology of Mineral Cycling: San Diego (Academic Press).

Fischer, J.P., Ferdelman, T.G., D'Hondt, S., Røy, H., and Wenzhöfer, F., 2009. Oxygen penetration deep into the sediment of the South Pacific Gyre. Biogeosciences, 6(8):1467-1478. doi:10.5194/bg-6-1467-2009

Fisher, A.T., Davis, E.E., Hutnak, M., Spiess, V., Zühlsdorff, L., Cherkaoui, A., Christiansen, L., Edwards, K., Macdonald, R., Villinger, H., Mottl, M.J., Wheat, C.G., and Becker, K., 2003. Hydrothermal recharge and discharge across $50 \mathrm{~km}$ guided by seamounts on a young ridge flank. Nature, 421(6923):618-621. doi:10.1038/ nature01352

Galy, V., France-Lanord, C., and Lartiges, B., 2008. Loading and fate of particulate organic carbon from the Himalaya to the Ganga-Brahmaputra Delta. Geochim. Cosmochim. Acta, 72(7):1767-1787. doi:10.1016/ j.gca.2008.01.027

Hartnett, H.E., and Devol, A.H., 2003. Role of a strong oxygen-deficient zone in the preservation and degradation of organic matter: a carbon budget for the continental margins of northwest Mexico and Washington state. Geochim. Cosmochim. Acta, 67(2):247-264. doi:10.1016/ S0016-7037(02)01076-1 
Hedges, J.I., Hu, F.S., Devol, A.H., Hartnett, H.E., Tsamakis, E., and Keil, R.G., 1999. Sedimentary organic matter preservation: a test for selective degradation under oxic conditions. Am. J. Sci., 299(7-9):529-555. doi:10.2475/ ajs.299.7-9.529

Hedges, J.I., and Stern, J.H., 1984. Carbon and nitrogen determinations of carbonate-containing solids. Limnol. Oceanogr., 29(3):657-663. doi:10.4319/ lo.1984.29.3.0657

Heuer, V.B., Pohlman, J.W., Torres, M.E., Elvert, M., and Hinrichs, K.-U., 2009. The stable carbon isotope biogeochemistry of acetate and other dissolved carbon species in deep subseafloor sediments at the northern Cascadia margin. Geochim. Cosmochim. Acta, 73(11):3323-3336. doi:10.1016/j.gca.2009.03.001

Holland, H.D., 1984. The Chemical Evolution of the Atmosphere and Oceans: Princeton, NJ (Princeton Univ. Press).

Holland, H.D., Lazar, B., and McCaffrey, M., 1986. Evolution of the atmosphere and oceans. Nature, 320:27-33. doi:10.1038/320027a0

Hutnak, M., Fisher, A.T., Zühlsdorff, L., Spiess, V., Stauffer, P.H., and Gable, C.W., 2006. Hydrothermal recharge and discharge guided by basement outcrops on 0.7-3.6 Ma seafloor east of the Juan de Fuca Ridge: observations and numerical models. Geochem., Geophys., Geosyst., 7(7):Q07O02. doi:10.1029/2006GC001242

Keil, R.G., and Fogel, M.L., 2001. Reworking of amino acid in marine sediments: stable carbon isotopic composition of amino acids in sediments along the Washington coast. Limnol. Oceanogr., 46(1):14-23. doi:10.4319/ 10.2001.46.1.0014

Keil, R.G., Mayer, L.M., Quay, P.D., Richey, J.E., and Hedges, J.I., 1997. Loss of organic matter from riverine particles in deltas. Geochim. Cosmochim. Acta, 61(7):1507-1511. doi:10.1016/S0016-7037(97)00044-6

Krom, M.D., and Sholkovitz, E.R., 1977. Nature and reactions of dissolved organic matter in the interstitial waters of marine sediments. Geochim. Cosmochim. Acta, 41(11):1565-1574. doi:10.1016/0016-7037(77)90168-5

Laanbroek, H.J., Veldkamp, H., Postgate, J.R., Lynch, J.M., and Le Roux, N., 1982. Microbial interactions in sediment communities [and discussion]. Philos. Trans. $R$. Soc., B, 297(1088):533-550. doi:10.1098/ rstb.1982.0059

Lang, S.Q., Butterfield, D.A., Lilley, M.D., Johnson, H.P., and Hedges, J.I., 2006. Dissolved organic carbon in ridge-axis and ridge-flank hydrothermal systems. Geochim. Cosmochim. Acta, 70(15):3830-3842. doi:10.1016/ j.gca.2006.04.031

Lin, H.-T., Cowen, J.P., Olson, E.J., Amend, J.P., and Lilley, M.D., 2012. Inorganic chemistry, gas compositions and dissolved organic carbon in fluids from sedimented young basaltic crust on the Juan de Fuca Ridge flanks. Geochim. Cosmochim. Acta, 85:213-227. doi:10.1016/ j.gca.2012.02.017
Meyers, P.A., 1994. Preservation of elemental and isotopic source identification of sedimentary organic matter. Chem. Geol., 114(3-4):289-302. doi:10.1016/00092541(94)90059-0

Michaelis, W., Mycke, B., Vogt, J., Schuetze, G., and Degens, E.T., 1982. Organic geochemistry of interstitial waters, Sites 474 and 479, Leg 64. In Curray, J.R., Moore, D.G., et al., Init. Repts. DSDP, 64: Washington, DC (U.S. Govt. Printing Office), 933-937. doi:10.2973/ dsdp.proc.64.139.1982

Papadimitriou, S., Kennedy, H., Bentaleb, I., and Thomas, D.N., 2002. Dissolved organic carbon in sediments from the eastern North Atlantic. Mar. Chem., 79(1):37-47. doi:10.1016/S0304-4203(02)00055-5

Prahl, F.G., Ertel, J.R., Goni, M.A., Sparrow, M.A., and Eversmeyer, B., 1994. Terrestrial organic carbon contributions to sediments on the Washington margin. Geochim. Cosmochim. Acta, 58(14):3035-3048. doi:10.1016/ 0016-7037(94)90177-5

Redfield, A.C., 1934. On the proportions of organic derivatives in sea water and their relation to the composition of plankton. In Daiel, R.J. (Ed.), James Johnson Memorial Volume: Liverpool (Univ. Press Liverpool), 177-192.

Seifert, R., Emeis, K.-C., Michaelis, W., and Degens, E.T., 1990. Amino acids and carbohydrates in sediments and interstitial waters from Site 681, Leg 112, Peru continental margin. In Suess, E., von Huene, R., et al., Proc. ODP, Sci. Results, 112: College Station, TX (Ocean Drilling Program), 555-566. doi:10.2973/ odp.proc.sr.112.152.1990

Sharp, J.H., Carlson, C.A., Peltzer, E.T., Castle-Ward, D.M., Savidge, K.B., and Rinker, K.R., 2002. Final dissolved organic carbon broad community intercalibration and preliminary use of DOC reference materials. Mar. Chem., 77(4):239-253. doi:10.1016/S0304-4203(02)00002-6

Simoneit, B.R.T., and Sparrow, M.A., 2002. Dissolved organic carbon in interstitial waters from sediments of Middle Valley and Escanaba Trough, Northeast Pacific, ODP Legs 139 and 169. Appl. Geochem., 17(11):14951502. doi:10.1016/S0883-2927(02)00114-2

Wefer, G., Berger, W.H., Richter, C., et al., 1998. Proc. ODP, Init. Repts., 175: College Station, TX (Ocean Drilling Program). doi:10.2973/odp.proc.ir.175.1998

Wheat, C.G., Hulme, S.M., Fisher, A.T., Orcutt B.N., and Becker, K., 2013. Seawater recharge into oceanic crust: IODP Exp. 327 Site U1363 Grizzly Bare outcrop. Geochem., Geophys., Geosyst., 14(6):1957-1972. doi:10.1002/ggge.20131

Initial receipt: 11 July 2014

Acceptance: 9 January 2015

Publication: 13 April 2015

MS 327-202 
Figure F1. A. Location of Grizzly Bare outcrop relative to the US continent. B. Bathymetric map of Site U1363. C. Reflection seismic profile across Holes U1363A-U1363G, showing sediment thickness increasing with distance from Grizzly Bare outcrop. The corresponding basement depths in Holes U1363G, U1363F, U1363B, and $\mathrm{U} 1363 \mathrm{C} / \mathrm{D}$ are $17,35,57$, and $231 \mathrm{mbsf}$, respectively.
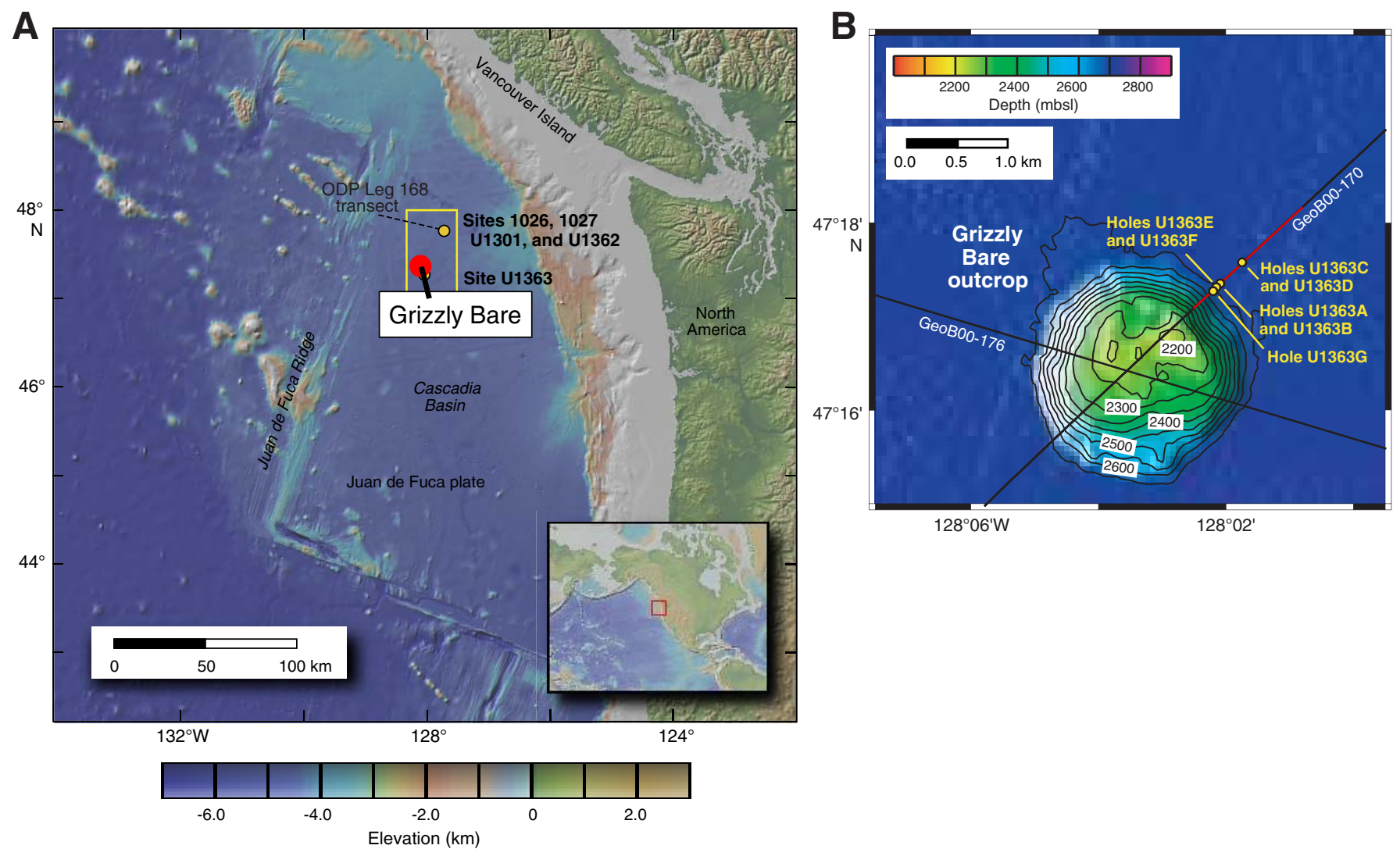

C sw

$\mathrm{NE}$

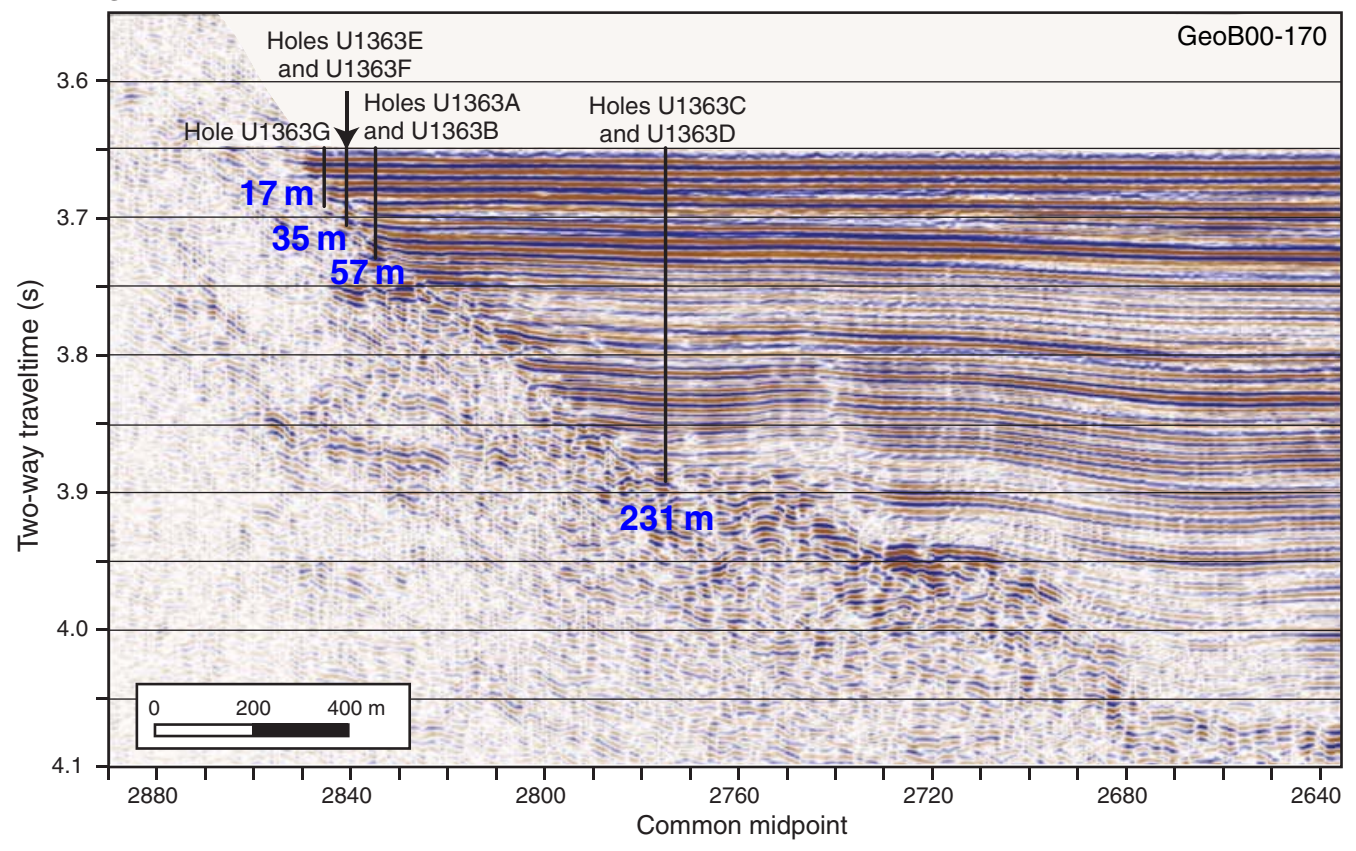


Figure F2. Dissolved organic carbon (DOC), sulfate, and alkalinity in pore water from retrieved sediment cores, Site U1363. All holes were sampled to within a few meters of the sediment/basement interface. Only the deepest $50 \mathrm{~m}$ of Holes U1363C and U1363D were cored. Sulfate and alkalinity data are from the "Site U1363" chapter (Expedition 327 Scientists, 2011b).
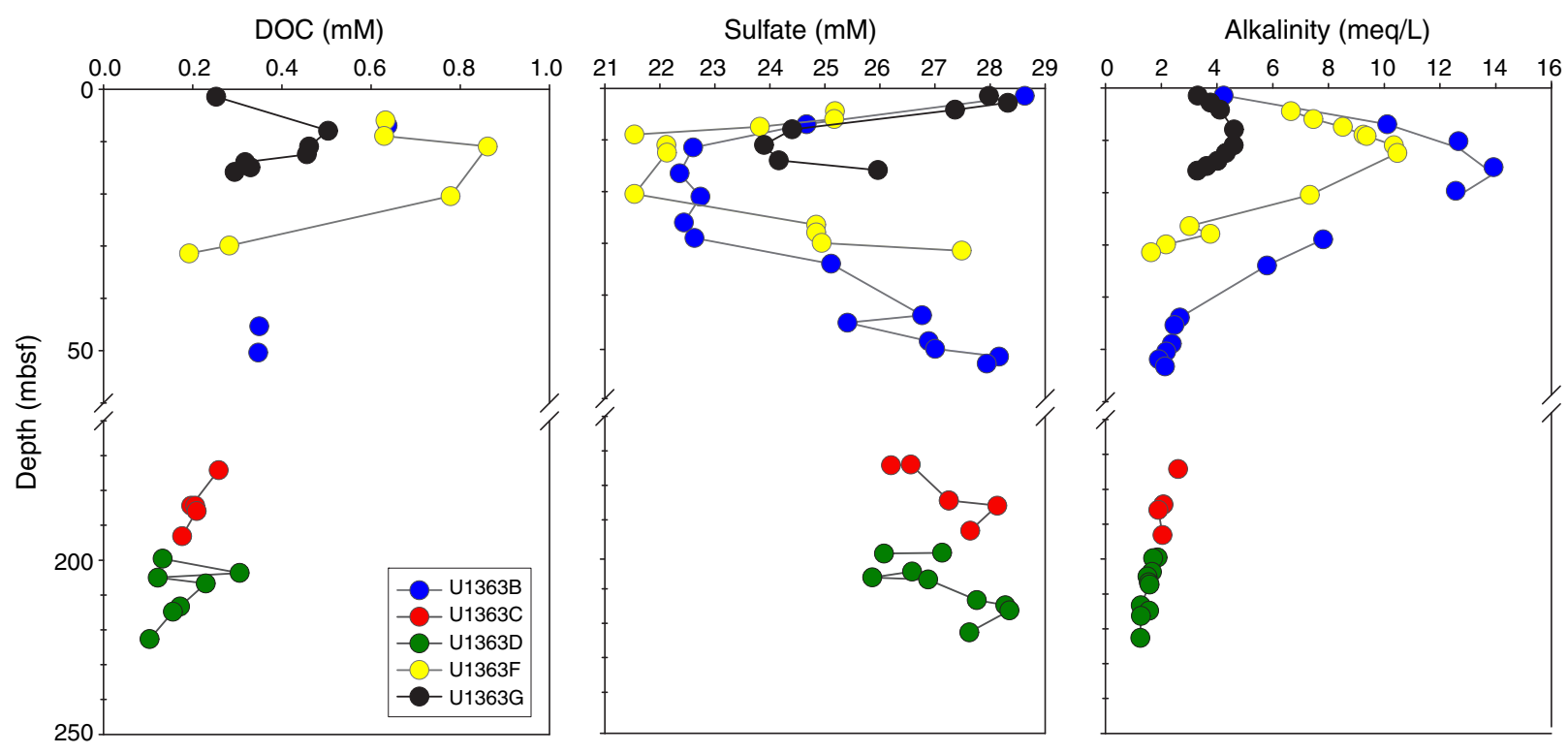
Figure F3. Relationship between concentrations of dissolved organic carbon (DOC) and sulfate or alkalinity in pore water from retrieved sediment cores, Site U1363.
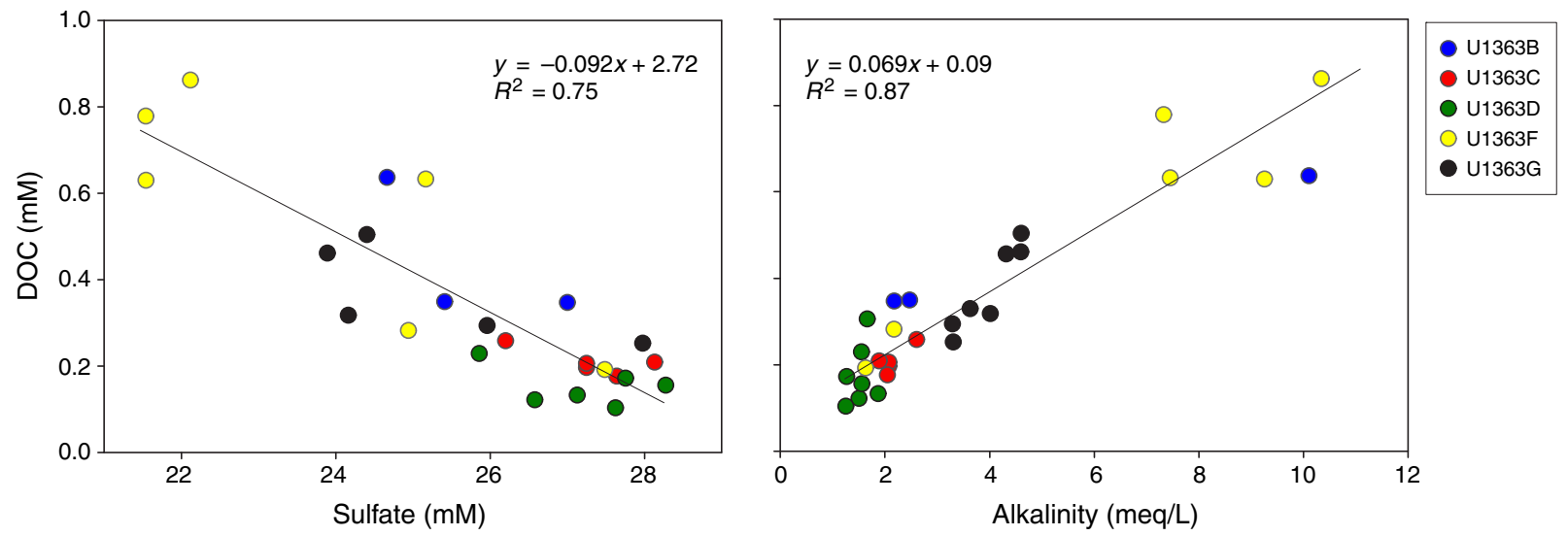
Figure F4. Plot of particulate organic carbon (POC) vs. dissolved organic carbon (DOC) concentrations, Site U1363.

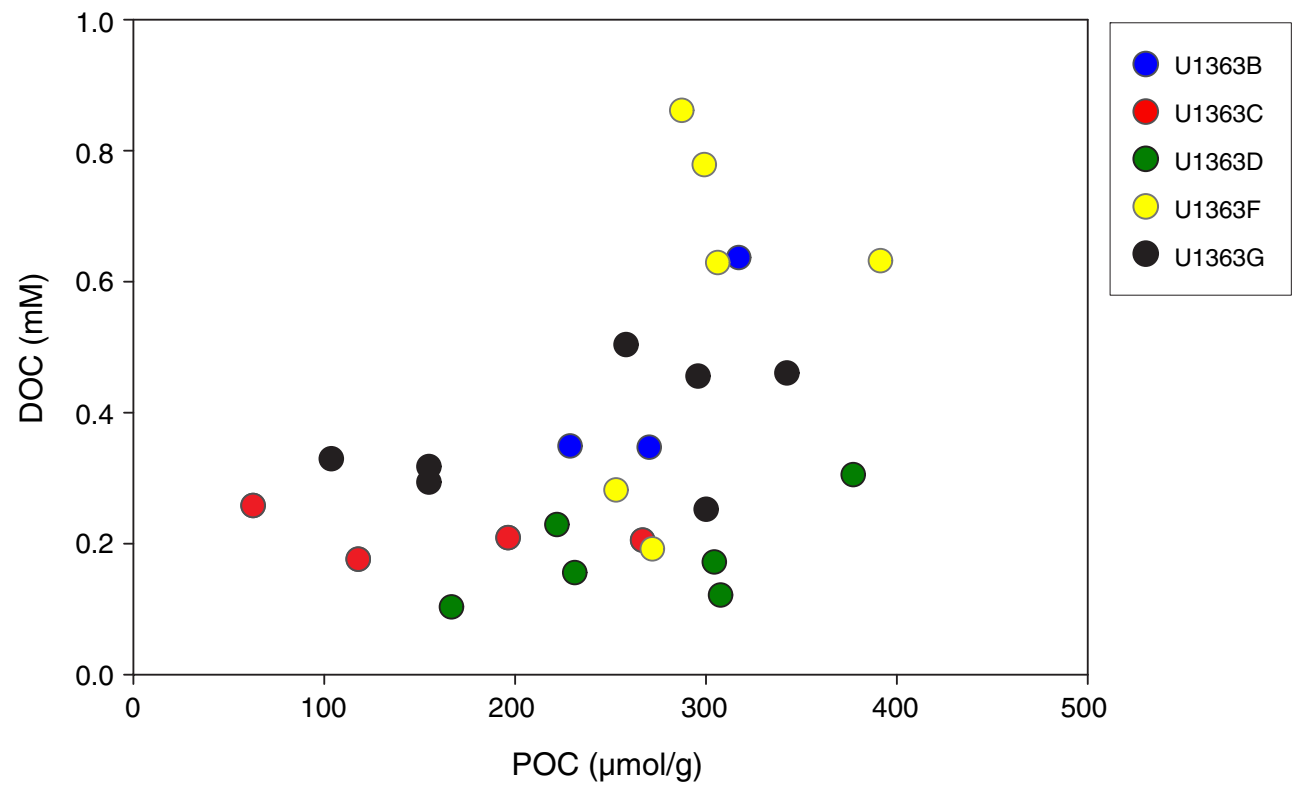


Figure F5. Particulate organic carbon (POC) and particulate nitrogen (PN) concentrations, POC/TN molar ratio, carbon isotopic compositions of POC, and nitrogen isotopic compositions of PN in whole sediments, Site U1363. Black dashed lines $=$ depths of sediment/basement interface, gray horizontal lines = sandy events (i.e., major turbidites; see also the "Site U1363" chapter [Expedition 327 Scientists, 2011b]).
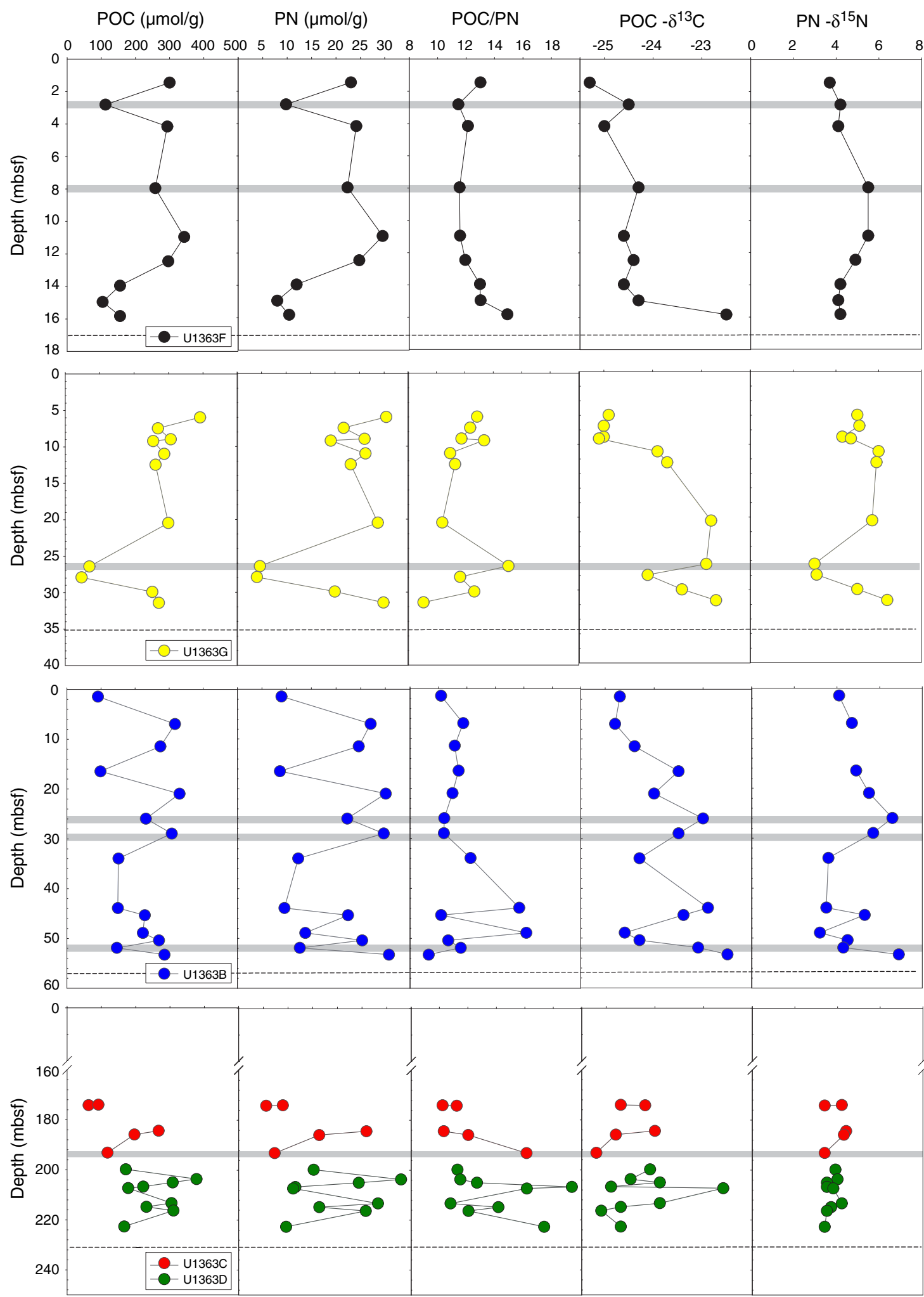
Figure F6. Plot of particulate organic carbon (POC) vs. total particulate nitrogen (PN) concentrations, Site U1363. Black line = least square regression line of all data points.

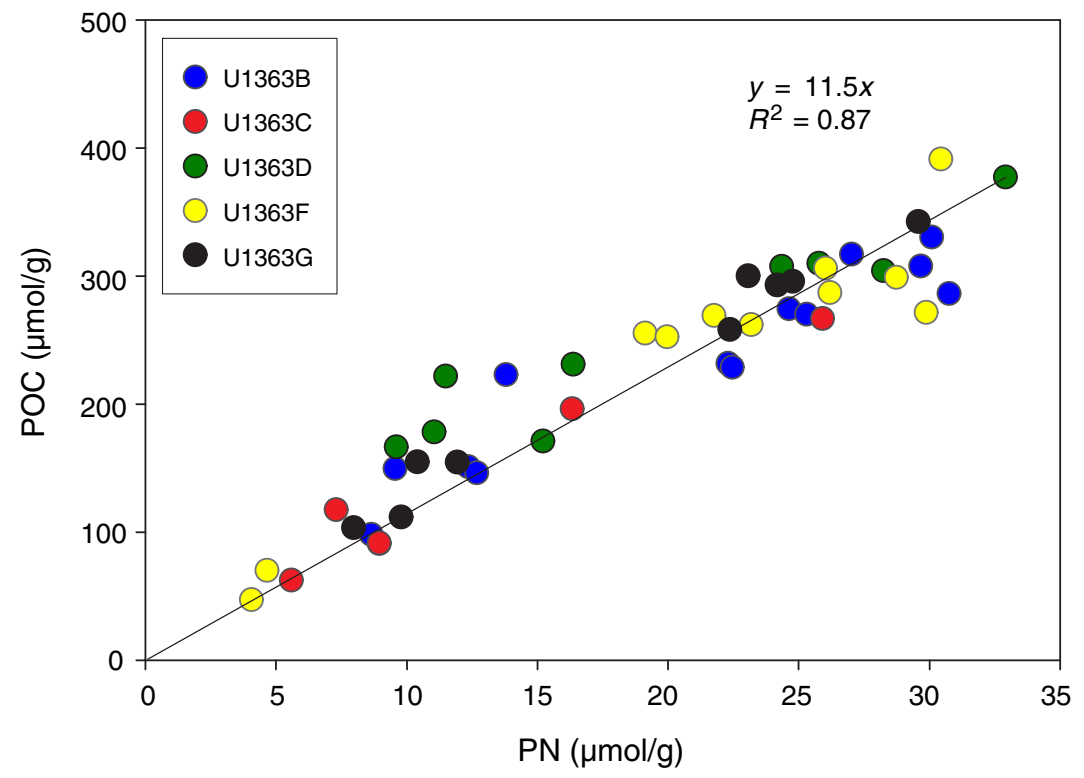


Figure F7. Relationships between the carbon isotopic composition of particulate organic carbon (POC), nitrogen isotopic composition of total particulate nitrogen (PN), and the POC/TN molar ratio in sediment samples, Site U1363. Suspended particle data are from seawater collected from a water column depth of $\sim 2600$ m above Site U1362 located $\sim 50 \mathrm{~km}$ northeast of Site U1363 (H.-T. Lin et al., unpubl. data, 2011). Data from plant debris, zooplankton, and phytoplankton are from Keil and Fogel (2001). Black dashed line $=$ Redfield ratio.
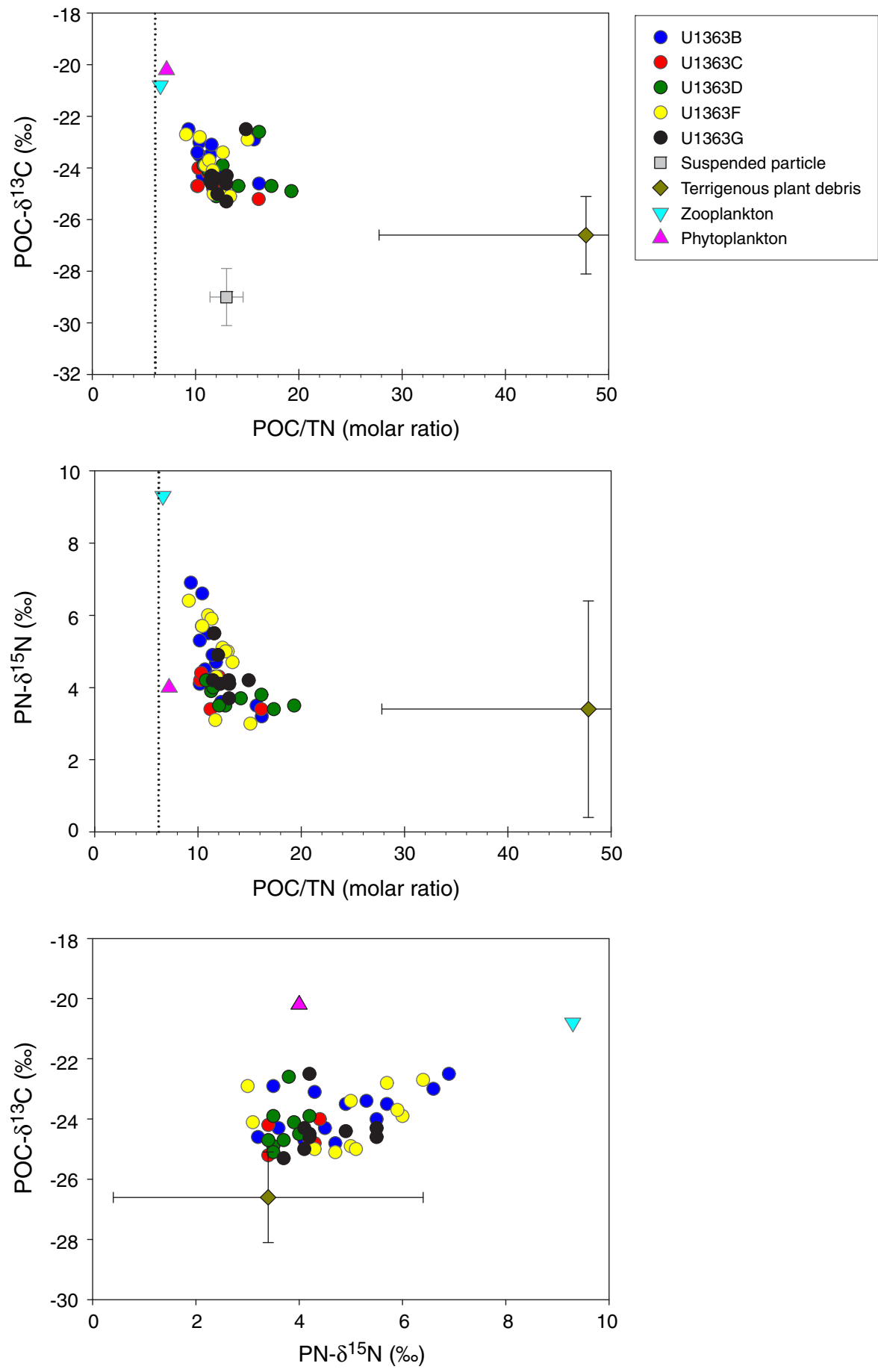
Table T1. Borehole locations, Site U1363.

\begin{tabular}{cccc}
\hline Hole & Latitude & Longitude & $\begin{array}{c}\text { Depth to } \\
\text { basement } \\
\text { (mbsf) }\end{array}$ \\
\hline $327-$ & & & \\
U1363B & $47^{\circ} 17.3518^{\prime} \mathrm{N}$ & $128^{\circ} 2.1060^{\prime} \mathrm{W}$ & 57.0 \\
U1363C & $47^{\circ} 17.5759^{\prime} \mathrm{N}$ & $128^{\circ} 1.7641^{\prime} \mathrm{W}$ & $\mathrm{NA}$ \\
U1363D & $47^{\circ} 17.5724^{\prime} \mathrm{N}$ & $128^{\circ} 1.7599^{\prime} \mathrm{W}$ & 231.2 \\
U1363F & $47^{\circ} 17.3261^{\prime} \mathrm{N}$ & $128^{\circ} 2.1374^{\prime} \mathrm{W}$ & 35.0 \\
U1363G & $47^{\circ} 17.3118^{\prime} \mathrm{N}$ & $128^{\circ} 2.1698^{\prime} \mathrm{W}$ & 17.0 \\
\hline
\end{tabular}

$\mathrm{NA}=$ not available 
Table T2. Pore water analyses results, Site U1363. (Continued on next page.)

\begin{tabular}{|c|c|c|c|c|c|c|c|c|c|c|c|c|c|c|c|c|c|}
\hline $\begin{array}{l}\text { Core, section, } \\
\text { interval }(\mathrm{cm})\end{array}$ & $\begin{array}{c}\text { Depth } \\
\text { average } \\
\text { (mbsf) }\end{array}$ & $\begin{array}{c}\text { TDC } \\
(\mathrm{mM})\end{array}$ & $\begin{array}{l}\mathrm{DOC} \\
(\mathrm{mM})\end{array}$ & $\begin{array}{c}\text { DIC } \\
(\mathrm{mM})\end{array}$ & $\begin{array}{c}\text { Acid-fumed } \\
\text { PN } \\
\text { (\%) }\end{array}$ & $\begin{array}{l}\text { POC } \\
(\%)\end{array}$ & $\begin{array}{c}\text { Acid-fumed } \\
\text { PN } \\
(\mu \mathrm{mol} / \mathrm{g})\end{array}$ & $\begin{array}{c}\text { POC } \\
(\mu \mathrm{mol} / \mathrm{g})\end{array}$ & $\begin{array}{c}\text { Acid-fumeo } \\
\text { PN- } \delta^{15} \mathrm{~N} \\
(\% \mathrm{o})\end{array}$ & $\begin{array}{c}\mathrm{POC}-\delta^{13} \mathrm{C} \\
(\% \mathrm{o})\end{array}$ & $\mathrm{C} / \mathrm{N}$ & $\begin{array}{l}\text { PN } \\
\text { (\%) }\end{array}$ & $\begin{array}{l}P C \\
(\%)\end{array}$ & $\begin{array}{c}\mathrm{PN}-\delta^{15} \mathrm{~N} \\
(\% 0)\end{array}$ & $\begin{array}{c}\mathrm{PC}-\delta^{13} \mathrm{C} \\
(\% 0)\end{array}$ & $\begin{array}{l}\text { PIC } \\
\text { (\%) }\end{array}$ & $\begin{array}{c}\mathrm{PIC}-\delta^{13} \mathrm{C} \\
(\% 0)\end{array}$ \\
\hline \multicolumn{18}{|l|}{ 327-U1363B- } \\
\hline $1 \mathrm{H}-1,1.4-1.5$ & 1.45 & NS & NS & NS & 0.013 & 0.11 & 9 & 91 & 4.1 & -24.7 & 10.2 & 0.012 & 0.33 & 3.5 & -7.9 & 0.22 & 0.1 \\
\hline $2 \mathrm{H}-3,6.9-7$ & 6.95 & 12.5 & 0.64 & 11.9 & 0.038 & 0.38 & 27 & 317 & 4.7 & -24.8 & 11.7 & 0.037 & 0.60 & 4.8 & -15.7 & 0.22 & -0.0 \\
\hline $2 \mathrm{H}-6,11.4-11.5$ & 11.45 & NS & NS & NS & 0.034 & 0.33 & 25 & 274 & 5.7 & -24.4 & 11.1 & 0.027 & 0.68 & 4.7 & -9.1 & 0.35 & 1.9 \\
\hline $3 \mathrm{H}-3,16.4-16.5$ & 16.45 & NS & NS & NS & 0.012 & 0.12 & 9 & 99 & 4.9 & -23.5 & 11.4 & 0.015 & 0.45 & 6.2 & -7.6 & 0.33 & -0.6 \\
\hline $3 \mathrm{H}-6,20.9-21$ & 20.95 & NS & NS & NS & 0.042 & 0.40 & 30 & 331 & 5.5 & -24.0 & 11.0 & 0.041 & 0.85 & 5.3 & -10.4 & 0.45 & 0.7 \\
\hline $4 \mathrm{H}-3,25.9-26$ & 25.95 & NS & NS & NS & 0.031 & 0.28 & 22 & 232 & 6.6 & -23.0 & 10.4 & 0.028 & 1.59 & 6.0 & -3.9 & 1.31 & 0.2 \\
\hline $4 \mathrm{H}-5,28.9-29$ & 28.95 & NS & NS & NS & 0.042 & 0.37 & 30 & 308 & 5.7 & -23.5 & 10.4 & 0.038 & 1.93 & 5.6 & -4.3 & 1.56 & 0.4 \\
\hline $5 \mathrm{H}-2,33.9-34$ & 33.95 & NS & NS & NS & 0.017 & 0.18 & 12 & 151 & 3.6 & -24.3 & 12.3 & 0.015 & 0.29 & 4.3 & -15.1 & 0.11 & 0.1 \\
\hline $7 X-1,43.8-44$ & 43.90 & NS & NS & NS & 0.013 & 0.18 & 10 & 150 & 3.5 & -22.9 & 15.7 & 0.013 & 0.40 & 3.2 & -11.6 & 0.22 & -0.5 \\
\hline $7 X-2,45.3-45.5$ & 45.35 & 2.6 & 0.35 & 2.3 & 0.031 & 0.27 & 22 & 229 & 5.3 & -23.4 & 10.2 & 0.030 & 1.20 & 5.0 & -4.9 & 0.93 & 0.5 \\
\hline $8 \mathrm{X}-1,48.8-49$ & 48.90 & NS & NS & NS & 0.019 & 0.27 & 14 & 223 & 3.2 & -24.6 & 16.2 & 0.020 & 0.37 & 4.7 & -17.9 & 0.11 & -0.1 \\
\hline $8 X-2,50.3-50.5$ & 50.40 & 2.3 & 0.35 & 1.9 & 0.035 & 0.32 & 25 & 270 & 4.5 & -24.3 & 10.7 & 0.035 & 0.66 & 4.3 & -11.3 & 0.34 & 0.4 \\
\hline $8 X-3,51.8-52$ & 51.90 & NS & NS & NS & 0.018 & 0.18 & 13 & 147 & 4.3 & -23.1 & 11.6 & 0.017 & 0.69 & 4.8 & -6.0 & 0.51 & -0.1 \\
\hline $8 X-5,53.2-53.4$ & 53.26 & NS & NS & NS & 0.043 & 0.34 & 31 & 286 & 6.9 & -22.5 & 9.3 & 0.044 & 2.94 & 5.9 & -1.6 & 2.60 & 3.0 \\
\hline \multicolumn{18}{|l|}{ 327-U1363C- } \\
\hline $3 \mathrm{X}-\mathrm{CC}, 174.1-174.3$ & 174.18 & 3.5 & 0.26 & 3.2 & 0.008 & 0.08 & 6 & 63 & 3.4 & -24.2 & 11.2 & 0.008 & 0.18 & 3.0 & -9.2 & 0.11 & 0.2 \\
\hline $3 X-1,173.9-174.1$ & 173.98 & NS & NS & NS & 0.013 & 0.11 & 9 & 91 & 4.2 & -24.7 & 10.2 & NA & NA & NA & NA & NA & NA \\
\hline $4 \mathrm{X}-1,184.3-184.5$ & 184.40 & 2.1 & 0.20 & 1.9 & NS & NS & NS & NS & NS & NS & NS & NS & NS & NS & NS & NS & NS \\
\hline $4 X-1,184.3-184.5$ & 184.40 & 2.2 & 0.21 & 2.0 & 0.036 & 0.32 & 26 & 267 & 4.4 & -24.0 & 10.3 & 0.034 & 1.44 & 4.0 & -5.5 & 1.12 & -0.2 \\
\hline $4 X-2,185.8-186$ & 185.90 & 2.3 & 0.21 & 2.1 & 0.023 & 0.24 & 16 & 196 & 4.3 & -24.8 & 12.0 & 0.022 & 0.60 & 4.3 & -9.6 & 0.36 & 0.1 \\
\hline $5 X-1,193.1-193.3$ & 193.15 & 2.7 & 0.18 & 2.5 & 0.010 & 0.14 & 7 & 118 & 3.4 & -25.2 & 16.1 & 0.009 & 0.27 & 3.4 & -12.9 & 0.13 & 0.1 \\
\hline \multicolumn{18}{|l|}{ 327-U1363D- } \\
\hline 2X-2, 199.7-199.9 & 199.80 & NS & NS & NS & 0.021 & 0.21 & 15 & 171 & 3.9 & -24.1 & 11.3 & 0.019 & 0.40 & 4.7 & -13.3 & 0.19 & -0.3 \\
\hline $3 X-1,203.5-203.9$ & 203.70 & 2.0 & 0.31 & 1.7 & 0.046 & 0.45 & 33 & 377 & 4.0 & -24.5 & 11.5 & 0.043 & 0.86 & 4.5 & -12.1 & 0.41 & 0.7 \\
\hline $3 X-2,205-205.1$ & 205.03 & 1.7 & 0.12 & 1.6 & 0.034 & 0.37 & 24 & 308 & 3.5 & -23.9 & 12.6 & 0.033 & 0.85 & 4.5 & -11.9 & 0.48 & -1.3 \\
\hline $3 X-3,206.5-206.9$ & 206.70 & 1.7 & 0.23 & 1.5 & 0.016 & 0.27 & 11 & 222 & 3.5 & -24.9 & 19.3 & 0.016 & 0.47 & 3.0 & -15.7 & 0.21 & -0.8 \\
\hline $3 X-4,207.1-207.5$ & 207.32 & NS & NS & NS & 0.015 & 0.21 & 11 & 178 & 3.8 & -22.6 & 16.1 & 0.016 & 0.37 & 3.8 & -15.2 & 0.15 & -0.8 \\
\hline $4 \mathrm{X}-1,213.1-213.5$ & 213.30 & 1.4 & 0.17 & 1.2 & 0.040 & 0.37 & 28 & 304 & 4.2 & -23.9 & 10.8 & 0.037 & 1.59 & 4.6 & -5.5 & 1.23 & -0.0 \\
\hline $4 X-2,214.6-215$ & 214.80 & 1.8 & 0.16 & 1.7 & 0.023 & 0.28 & 16 & 231 & 3.7 & -24.7 & 14.1 & 0.023 & 0.44 & 3.8 & -16.4 & 0.16 & -0.3 \\
\hline $4 X-3,216.1-216.5$ & 216.30 & NS & NS & NS & 0.036 & 0.37 & 26 & 310 & 3.5 & -25.1 & 12.0 & 0.037 & 0.65 & 4.3 & -15.0 & 0.27 & -0.4 \\
\hline $5 X-1,222.5-222.9$ & 222.65 & 1.6 & 0.10 & 1.5 & 0.013 & 0.20 & 10 & 167 & 3.4 & -24.7 & 17.4 & 0.014 & 0.38 & 4.0 & -14.5 & 0.18 & -0.6 \\
\hline \multicolumn{18}{|l|}{ 327-U1363F- } \\
\hline $1 \mathrm{H}-3,4.4-4.5$ & 4.45 & NS & NS & NS & NA & NA & NA & NA & NA & NA & NA & 0.033 & 0.61 & 4.6 & -12.8 & NA & NA \\
\hline $1 \mathrm{H}-4,5.9-6$ & 5.95 & 8.9 & 0.63 & 8.3 & 0.043 & 0.47 & 30 & 391 & 5.0 & -24.9 & 12.9 & 0.041 & 0.73 & 5.4 & -15.4 & 0.26 & 0.4 \\
\hline $1 \mathrm{H}-5,7.4-7.5$ & 7.45 & NS & NS & NS & 0.030 & 0.32 & 22 & 269 & 5.1 & -25.0 & 12.4 & 0.029 & 0.58 & 5.6 & -13.9 & 0.26 & 0.0 \\
\hline $1 \mathrm{H}-6,8.9-9$ & 8.95 & 10.7 & 0.63 & 10.1 & 0.036 & 0.37 & 26 & 306 & 4.3 & -25.0 & 11.8 & 0.034 & 0.55 & 4.9 & -16.3 & 0.18 & 0.2 \\
\hline $1 \mathrm{H}-7,9.1-9.2$ & 9.19 & NS & NS & NS & 0.027 & 0.31 & 19 & 255 & 4.7 & -25.1 & 13.4 & 0.028 & 0.59 & 5.6 & -13.2 & 0.29 & -0.1 \\
\hline $2 \mathrm{H}-1,10.9-11$ & 10.95 & 12.4 & 0.86 & 11.5 & 0.037 & 0.34 & 26 & 287 & 6.0 & -23.9 & 11.0 & 0.036 & 1.00 & 6.5 & -7.9 & 0.66 & 0.3 \\
\hline $2 \mathrm{H}-2,12.4-12.5$ & 12.45 & NS & NS & NS & 0.032 & 0.31 & 23 & 262 & 5.9 & -23.7 & 11.3 & 0.028 & 0.86 & 4.3 & -7.5 & 0.55 & 1.0 \\
\hline $3 \mathrm{H}-1,20.4-20.5$ & 20.45 & 8.9 & 0.78 & 8.2 & 0.040 & 0.36 & 29 & 299 & 5.7 & -22.8 & 10.4 & 0.039 & 0.96 & 5.7 & -8.4 & 0.60 & 0.2 \\
\hline $3 \mathrm{H}-5,26.4-26.5$ & 26.41 & NS & NS & NS & 0.007 & 0.08 & 5 & 70 & 3.0 & -22.9 & 15.1 & 0.009 & 0.35 & 1.8 & -7.8 & 0.26 & -0.8 \\
\hline $3 \mathrm{H}-6,27.9-28$ & 27.91 & NS & NS & NS & 0.006 & 0.06 & 4 & 47 & 3.1 & -24.1 & 11.7 & 0.006 & 0.25 & 2.3 & -8.6 & 0.20 & -0.8 \\
\hline $4 \mathrm{H}-1,29.8-30$ & 29.90 & 2.8 & 0.28 & 2.5 & 0.028 & 0.30 & 20 & 253 & 5.0 & -23.4 & 12.7 & 0.027 & 0.71 & 5.0 & -10.3 & 0.41 & -0.2 \\
\hline $4 \mathrm{H}-2,31.3-31.5$ & 31.40 & 2.2 & 0.19 & 2.0 & 0.042 & 0.33 & 30 & 272 & 6.4 & -22.7 & 9.1 & 0.039 & 0.52 & 6.2 & -13.2 & 0.20 & 0.5 \\
\hline
\end{tabular}


Table T2 (continued).

\begin{tabular}{|c|c|c|c|c|c|c|c|c|c|c|c|c|c|c|c|c|c|}
\hline $\begin{array}{l}\text { Core, section, } \\
\text { interval }(\mathrm{cm})\end{array}$ & $\begin{array}{l}\text { Depth } \\
\text { average } \\
\text { (mbsf) }\end{array}$ & $\begin{array}{l}\text { TDC } \\
(\mathrm{mM})\end{array}$ & $\begin{array}{l}\mathrm{DOC} \\
(\mathrm{mM})\end{array}$ & $\begin{array}{c}\text { DIC } \\
(\mathrm{mM})\end{array}$ & $\begin{array}{c}\text { Acid-fumed } \\
\text { PN } \\
(\%)\end{array}$ & $\begin{array}{l}\text { POC } \\
(\%)\end{array}$ & $\begin{array}{c}\text { Acid-fumed } \\
\text { PN } \\
(\mu \mathrm{mol} / \mathrm{g})\end{array}$ & $\begin{array}{c}\text { POC } \\
(\mu \mathrm{mol} / \mathrm{g})\end{array}$ & $\begin{array}{c}\text { Acid-fumed } \\
\text { PN- } \delta^{15} N \\
(\% \circ)\end{array}$ & $\begin{array}{c}\text { POC- } \delta^{13} \mathrm{C} \\
(\% 0)\end{array}$ & $\mathrm{C} / \mathrm{N}$ & $\begin{array}{l}\text { PN } \\
(\%)\end{array}$ & $\begin{array}{l}P C \\
(\%)\end{array}$ & $\begin{array}{c}\mathrm{PN}-\delta^{15} \mathrm{~N} \\
(\% \circ)\end{array}$ & $\begin{array}{c}\mathrm{PC}-\delta^{13} \mathrm{C} \\
(\% 0)\end{array}$ & $\begin{array}{l}\text { PIC } \\
\text { (\%) }\end{array}$ & $\begin{array}{c}\text { PIC- } \delta^{13} \mathrm{C} \\
(\% 0)\end{array}$ \\
\hline \multicolumn{18}{|l|}{ 327-U1363G- } \\
\hline $1 \mathrm{H}-1,1.4-1.5$ & 1.45 & 4.0 & 0.25 & 3.7 & 0.032 & 0.36 & 23 & 300 & 3.7 & -25.3 & 13.0 & 0.033 & 0.56 & 4.7 & -16.0 & 0.20 & 0.1 \\
\hline $1 \mathrm{H}-2,2.8-2.9$ & 2.81 & NS & NS & NS & 0.014 & 0.13 & 10 & 112 & 4.2 & -24.5 & 11.5 & 0.015 & 0.50 & 5.2 & -9.0 & 0.37 & -1.2 \\
\hline $1 \mathrm{H}-3,4.1-4.3$ & 4.15 & NS & NS & NS & 0.034 & 0.35 & 24 & 293 & 4.1 & -25.0 & 12.1 & 0.032 & 0.54 & 4.6 & -16.1 & 0.18 & 0.2 \\
\hline $2 \mathrm{H}-1,7.9-8$ & 7.95 & 6.3 & 0.50 & 5.8 & 0.031 & 0.31 & 22 & 258 & 5.5 & -24.3 & 11.5 & 0.031 & 0.93 & 5.3 & -8.8 & 0.62 & -0.7 \\
\hline $2 \mathrm{H}-3,10.9-11$ & 10.95 & 6.1 & 0.46 & 5.7 & 0.041 & 0.41 & 30 & 342 & 5.5 & -24.6 & 11.6 & 0.042 & 0.72 & 5.2 & -14.9 & 0.31 & -0.6 \\
\hline $2 \mathrm{H}-4,12.4-12.5$ & 12.45 & 5.8 & 0.46 & 5.4 & 0.035 & 0.36 & 25 & 296 & 4.9 & -24.4 & 11.9 & 0.029 & 0.60 & 5.2 & -11.4 & 0.24 & 1.8 \\
\hline $2 \mathrm{H}-5,13.9-14$ & 13.95 & 4.8 & 0.32 & 4.5 & 0.017 & 0.19 & 12 & 155 & 4.2 & -24.6 & 13.0 & 0.017 & 0.49 & 3.4 & -10.7 & 0.30 & -0.6 \\
\hline $2 \mathrm{H}-6,14.9-15$ & 14.95 & 5.9 & 0.33 & 5.6 & 0.011 & 0.12 & 8 & 104 & 4.1 & -24.3 & 13.0 & 0.011 & 0.39 & 3.3 & -9.5 & 0.27 & -0.7 \\
\hline $2 \mathrm{H}-7,15.7-15.9$ & 15.82 & 4.5 & 0.29 & 4.2 & 0.015 & 0.19 & 10 & 155 & 4.2 & -22.5 & 14.9 & 0.014 & 0.75 & 4.0 & -6.2 & 0.56 & -0.5 \\
\hline \multicolumn{18}{|l|}{ Flow-in samples: } \\
\hline \multicolumn{18}{|l|}{ 327-U1363G- } \\
\hline $3 \mathrm{H}-1,17.4-17.5$ & 17.45 & 4.1 & 0.81 & 3.3 & 0.033 & 0.28 & 23 & 233 & 7.2 & -22.6 & 10.0 & 0.032 & 1.31 & 6.6 & -4.8 & 1.03 & 0.0 \\
\hline $3 \mathrm{H}-2,18.9-19$ & 18.95 & NS & NS & NS & 0.035 & 0.30 & 25 & 252 & 6.7 & -22.7 & 10.0 & 0.035 & 1.50 & 6.4 & -4.7 & 1.20 & -0.2 \\
\hline $3 \mathrm{H}-3,20.4-20.5$ & 20.45 & 4.3 & 0.89 & 3.4 & 0.035 & 0.29 & 25 & 242 & 6.8 & -22.4 & 9.6 & 0.034 & 1.33 & 6.8 & -4.8 & 1.04 & 0.1 \\
\hline $3 \mathrm{H}-4,21.9-22$ & 21.95 & 4.5 & 0.97 & 3.6 & 0.034 & 0.28 & 24 & 233 & 6.9 & -22.6 & 9.7 & 0.033 & 1.50 & 7.2 & -4.0 & 1.22 & 0.3 \\
\hline $3 \mathrm{H}-5,23.4-23.5$ & 23.45 & 4.6 & 0.93 & 3.7 & 0.028 & 0.24 & 20 & 198 & 6.3 & -22.9 & 9.8 & 0.028 & 1.37 & 5.7 & -3.8 & 1.13 & 0.2 \\
\hline $3 \mathrm{H}-6,24.5-24.7$ & 24.59 & 5.0 & 0.77 & 4.2 & 0.026 & 0.23 & 19 & 192 & 5.8 & -23.4 & 10.3 & 0.025 & 1.34 & 5.5 & -4.3 & 1.11 & -0.4 \\
\hline
\end{tabular}

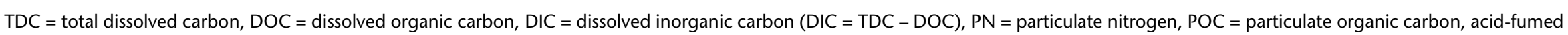
$\mathrm{PN}, \mathrm{PC}=$ particulate carbon, $\mathrm{PIC}=$ particulate inorganic carbon. NS $=$ not sampled, NA = not analyzed. 